\title{
Groundwater-mediated limnology in Spain
}

\author{
Miguel Álvarez-Cobelas
}

\author{
Instituto de Recursos Naturales, CSIC, Serrano 115 dpdo., 28006 Madrid, Spain, malvarez@ccma.csic.es
}

\begin{abstract}
Despite the obvious relationship between groundwater and surface waters, only a few studies have indirectly addressed the effects of groundwater on Spanish limnosystems, although there are many suggesting that such effects may be important. I present here an overview reporting such effects, which affect water balance, motions of lake layers, underwater light climate, conservative hydrochemisty and nutrients, and community structure and dynamics, some of which are time-delayed. Future Spanish studies on groundwater-mediated limnology will be fostered if regionally oriented hydrogeologists meet locally oriented limnologists and they exchange their knowledge and perform joint research. These efforts will result in updating and expanding the ideas of regional limnology that Naumann and Margalef have promoted.
\end{abstract}

Keywords: water renewal, Mediterranean limnosystems, regional hydrogeology, landscape, regional limnology

\section{RESUMEN}

A pesar de la relación obvia entre las aguas subterráneas y las superficiales, sólo algunos estudios han considerado indirectamente los efectos que las primeras pueden tener sobre los limnosistemas españoles, aunque haya numerosas sugerencias de que tales efectos puedan ser importantes. Aqui presento una breve revisión de dichos efectos, los cuales afectan al balance hídrico, a los movimientos de las capas lacustres, al ambiente luminoso subacuático, a la hidroquímica conservativa y los nutrientes y a la estructura y dinámica de las comunidades biológicas, y algunos de los cuales presentan desfases temporales. En el futuro, los estudios de limnología relacionada con las aguas subterráneas serán más interesantes cuando los hidrogeólogos de enfoque regional se mezclen con los limnólogos de enfoque local y ambos grupos intercambien conocimientos y realicen investigaciones conjuntas, lo cual dará como resultado la actualización y expansión de las ideas de la limnología regional que Naumann y Margalef emitieran en su día.

Palabras clave: renovación del agua, limnosistemas mediterráneos, hidrogeología regional, paisaje, limnología regional

\section{RESUM}

A pesar de la relació òbvia entre les aigües subterrànies $i$ les superficials, tan sols alguns estudis han considerat indirectament els efectes que les primeres poden tenir sobre els limnosistemes espanyols, encara que existeixen nombrosos suggeriments que indiquen que aquests efectes poden ser importants. Aquí presento una breu revisió d'aquests efectes, els quals afecten al balanç hídric, als moviments de les capes lacustres, a l'ambient lluminós subaquàtic, a la hidroquímica conservativa i als nutrients $i$ a l'estructura i dinàmica de les comunitats biològiques, i alguns dels quals presenten desfasaments temporals. En el futur, els estudis de limnologia relacionada amb les aigües subterrànies es veuran impulsats si els hidrogeòlegs d'enfocament regional es barregen amb els limnòlegs d'enfocament local i ambdós grups s'intercanvien coneixements $i$ realitzen investigacions conjuntes. Això tindrà com a resultat l'actualització i expansió de les idees de la limnologia regional que Naumann $i$ Margalef varen emetre el seu dia.

Paraules clau: renovació de l'aigua, limnosistemes mediterrànis, hidrogeologia regional, limnologia regional.

Colc, Senyor Déu, la Figura Carnal, Els cels fecunds que il.lustren l'Oceà, Els rius subtils eixits d'un ull llunyà, El Pic, la Vall i el Pla; l'Ordre Cabdal J.V. FoIx (1936)

MARGALEF (at the $13^{\text {th }}$ SIL Congress in Finland): Les régions calcaires à érosion karstique sont très développées en Espagne... Je distingue en Espagne deux types principaux de lacs permanents dans ces régions, qu'on pourrait définir respectivement par la provenance superficielle ou profonde des eaux... (in Stankoviç, 1958) 


\section{INTRODUCTION}

Noel Hynes' (1975) seminal paper, which was published after his conference at the $19^{\text {th }}$ SIL Congress, held in Canada, certainly opened a new research field and a new scale of observation for limnological topics, which became more fruitful some 20 years later with the advent of GIS methodologies (Johnson \& Gage, 1997). Hynes disclosed basin effects on in-stream ecological dynamics, and hence an astonishing view of terrestrial landscape influences on aquatic environments was fostered.

Thomas Winter's efforts have not been as successful as Hynes'. His attempts to promote the importance of groundwater in limnology, in spite of being sustained over time, have not reached a receptive and widespread limnological audience, as deserved by the topic. Anyway, he is to be credited for his efforts (Winter, 1981, $1988,1995,1999,2003)$ to convince limnologists of the paramount significance of groundwater for freshwater ecology. This is particularly true in Mediterranean environments because the seasonal rainfall usually recharges aquifers that then experience delayed discharge during dry periods, thus supplying water to many limnosystems that would be dry otherwise (ÁlvarezCobelas et al., 2005a).

Spain has 370 aquifers (Table 1), spreading over some $167,000 \mathrm{~km}^{2}$ (roughly $30 \%$ of overall peninsular area) in all basins. The effects of groundwater on limnosystems concern the quantity and quality of freshwater, which in turn affect most limnological features. One hundred and one wetlands bigger than $10 \mathrm{Ha}$ are acknowledged to be influenced by groundwater in Spain (Table 2). Despite these figures, only a few recent studies report the important role that groundwater plays in Spanish limnosystems (Table 3), and most of that recognition is in passing only. Obviously, this poor outcome arises from the almost non-existent relationships between Spanish ecologists and hydrogeologists, that pioneering studies by González Bernáldez (1992a) attempted to foster, but whose efforts were stopped by his untimely death. However, the intimacy between surface and groundwater in Spain has long been recognized in popular culture, a proof of which is the high number of topographic names related to groundwater upwelling throughout Spain (http://pci204.cindoc.csic.es/tesauros/Toponimo/Toponimo.htm)

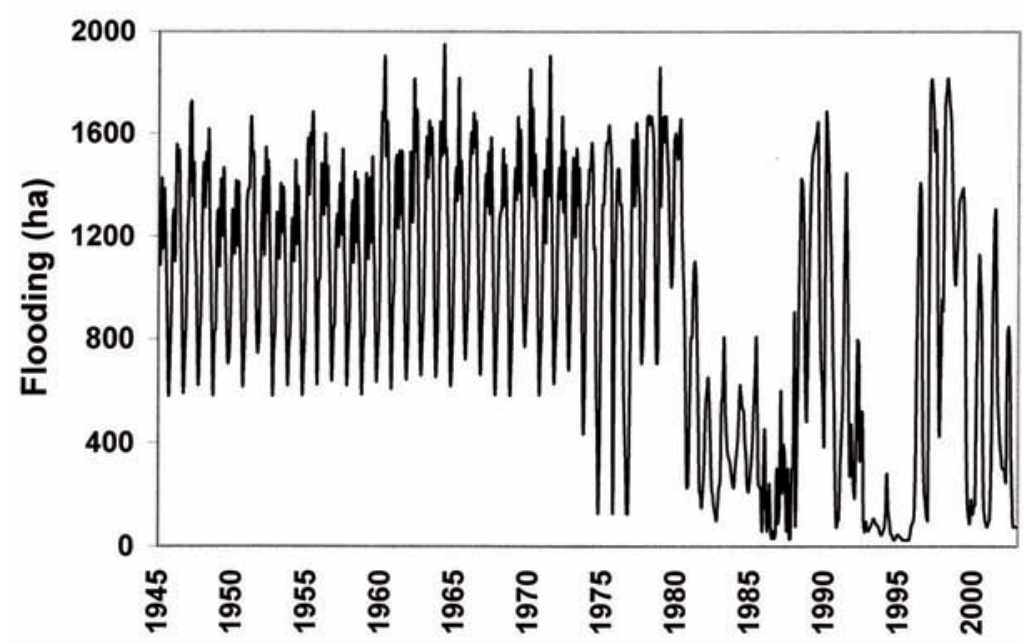

Figure 1. Long-term flooding in Las Tablas de Daimiel wetland, a National Park since 1973. Since 1986 groundwater supply was discontinued due to aquifer overexploitation. Later, flooding was partly artificially induced by water transference from the nearby Tajo basin, though high rainfall and groundwater discharge from a nearby aquifer (Campo de Montiel) have been responsible for the 1997-1998 peaks. Data source: Tablas de Daimiel National Park and Álvarez-Cobelas (unpublished data). Inundación a largo plazo de Las Tablas de Daimiel, que desde 1973 es Parque Nacional. Desde 1986 no hay aportes de aguas subterráneas debido a la sobreexplotación del acuífero. Después, la inundación se ha conseguido en parte de manera artificial, mediante trasvase desde la cuenca del Tajo, si bien las elevadas pluviosidad y descarga desde un acuífero cercano (el del Campo de Montiel) han sido responsables de los máximos en 1997 y 1998. Fuente: Parque Nacional Tablas de Daimiel y Álvarez-Cobelas (datos inéditos). 
Table 1. Overall area of aquifers in Spanish hydrographic basins. Data source: Martín Pantoja et al. (1994). Extensión de los acuiferos en las cuencas hidrográficas españolas. Fuente: Martín Pantoja et al. (1994).

\begin{tabular}{lcc}
\hline $\begin{array}{l}\text { Catchment/ } \\
\text { Cuenca }\end{array}$ & $\begin{array}{c}\text { Number of aquifers/ } \\
\boldsymbol{N}^{\boldsymbol{o}} \text { acuiferos }\end{array}$ & $\begin{array}{c}\text { Permeable areas }\left(\mathbf{k m}^{\mathbf{2}}\right) / \\
\text { Zonas permeables }\end{array}$ \\
\hline Northern & 24 & 7,009 \\
Duero & 21 & 53,623 \\
Tajo & 12 & 15,961 \\
Guadiana & 13 & 11,960 \\
Guadalquivir & 48 & 13,811 \\
Guadalete-Barbate & 12 & 1,486 \\
Southern & 46 & 3,138 \\
Segura & 32 & 8,603 \\
Júcar & 52 & 24,782 \\
Ebro & 45 & 16,770 \\
Inner Catalonia & 30 & 6,463 \\
Balearic Islands & 35 & 3,618 \\
Total & 370 & 167,224 \\
\hline
\end{tabular}

and the richness of limnosystem names in Spanish (González-Bernáldez, 1992b) and Mediterranean areas (Alvarez-Cobelas et al., 2005a).

Groundwater effects on water quantity act upon stream discharge and water balance in lakes and wetlands. Sometimes, groundwater inflows may even trigger motions of water and solutes within limnobasins. Also, groundwater supply may affect emergent plant structure and dynamics in wetlands. Aquifer water quality impinges on the chemistry of limnosystems, either conservative or not, thus indirectly changing ionic composition and nutrient concentrations that shape inland water metabolism, sensu Golterman (1975), and biota.

This overview will briefly describe the studies on the interaction between groundwater and freshwater systems in Spain to end up with some prospects for the discipline. Hyporheic effects, however, will not be dealt with here.

\section{WATER BALANCE EFFECTS}

These are the effects having paramount importance for limnosystems. They have often been addressed, albeit without frequent quantification. Lake and wetland levels and stream discharges are increased by groundwater inputs in many areas of Spain, those inputs being the sole ones in some seasons. Thus groundwater enhances water availability and renewal for many Spanish limnosystems and enables rich biota to thrive.

The oldest known process of groundwater supply to a Spanish limnosystem is perhaps that of the Upper Guadiana River (HernándezPacheco, 1932), which relied on a very old idea (Pliny the Elder, $1^{\text {st }}$ century AC; 1998 edition) of an underground stream passage. Upper Guadiana has been believed to infiltrate North of Lagunas de Ruidera and upwell in Ojos del Guadiana, some $50 \mathrm{~km}$ west. This idea, of strong metaphoric power over time (any person, fact or process appearing and disappearing in Spain is thought to be like the Guadiana River in modern speaking and the mass media), was scientifically discredited 30 years ago (Torrens et al., 1976), but it is still receiving strong affection, maybe because it is cited in Cervantes' Don Quixote ( $2^{\text {nd }}$ part, chapter XXIII). Anyway, long-range groundwater has upwelled in a large spring, called Ojos del Guadiana ("Guadiana Eyes"), until 1986 when such an upwelling has been over because of aquifer overexploitation for irrigation purposes (Álvarez-Cobelas \& Cirujano, 1996).

The significance of the groundwater supply at the Ojos del Guadiana spring for the nearby Tablas de Daimiel wetland has been very high. A roughly constant volume of water has emerged for decades, flooding an area that in the fifties extended over more than $200 \mathrm{~km}^{2}$ (ÁlvarezCobelas \& Cirujano, 1996). For many years, the wetland experienced a seasonal pattern of flooding (Fig. 1) that began changing in the seventies, when man-made activities strongly impacted the wetland, a National Park by then. That groundwater of low ionic strength has merged with intermittent stream water of higher salinity to provide a mixed environment, very suitable for a high species richness biota (Álvarez-Cobelas \& Cirujano, 1996). In 1986 the spring no longer upwelled, and flooding of this wetland has lacked a predictable pattern since then (Fig. 1). Other wetlands where groundwater effects on water availability have been reported are those of Duero basin (Ávila-Valladolid; Rey-Benayas, 1991), La Safor (Valencia; Rodrigo et al., 2001) and L'Empordá (Girona; Quintana, 2002). 


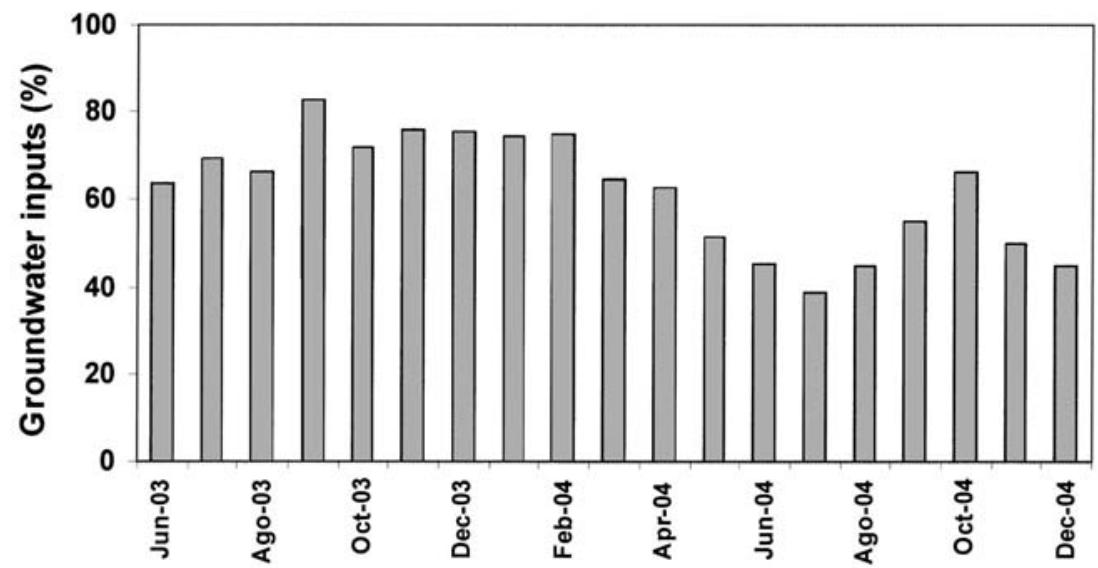

Figure 2. Groundwater percentage of water inputs (subaquatic and shoreline springs) to the Colgada lake (Ruidera lake complex, Central Spain) in 2003 and 2004. Inputs of subaquatic springs comprise 47-89\% of overall groundwater entering the lake. Unpublished data. Porcentaje de los aportes hídricos de origen subterráneo (fuentes subacuáticas y manantiales litorales) a la laguna Colgada (complejo lacustre de Ruidera, Centro de España) en 2003 y 2004. Las entradas subacuáticas representan un $47-$ $89 \%$ del total de las aguas subterráneas que entran al lago. Datos inéditos.

Groundwater flows into lakes were recognized more recently. Margalef reported groundwater delivery in the Banyoles Lake in the same presentation of Stankoviç (1958), the evidence dating back to the early $20^{\text {th }}$ century (Vidal-Pardal, 1960). In the eighties the study of groundwater upwelling in Banyoles started, as related to the sediment resuspension process (Roget \& Casamitjana, 1986). Entering mostly through the southern basins of the lake, groundwater inflows ranged 1.6-5.1 $10^{4} \mathrm{~m}^{3} \mathrm{~d}^{-1}$, being 4-fold of surface inflows (table 2 of Casamitjana \& Roget, 1993) and lacking strong seasonality.

The Ruidera Lakes, comprised of 18 flowthrough, seepage basins, have also been known to experience groundwater supply for long, but its measurement has started very recently (CEDEX, 1997). More than a half of overall water supply received by the Colgada Lake (one of the largest basins of that lake complex) is of groundwater origin (Fig. 2), amounting to $7-14 \cdot 10^{4} \mathrm{~m}^{3} \mathrm{~d}^{-1}$ in 2003-2004. A slight seasonality is obvious in the groundwater supply of Colgada Lake in that picture, taken in years of high water availability, but such a seasonality wanes as rainfall becomes lower than the annual average $(450 \mathrm{~mm}$; Álvarez-Cobelas, unpublished data). These lakes are strongly dependent on the interplay among rainfall, surface- and groundwater, which -when sufficient- enhance lake connectivity, albeit showing delays of up to nine months from strong rainfall to surface connection of all lakes (Álvarez-Cobelas, unpublished data). As a result, their water renewal time happens to be highly variable (Table 4), and this has overwhelming effects on limnological features of Ruidera lakes (Álvarez-Cobelas et al., submitted).

Since groundwater regional flow is a very complex phenomenon (Tóth, 1963), it is not surprising that some lakes experience sudden net groundwater inflow, irrespective to rainfall seasonality. This has been observed in the

Table 2. Wetlands larger than $10 \mathrm{Ha}$ connected to aquifers in Spain. Data source: Martín Pantoja et al. (1994). Humedales de más de 10 Ha conectados a acuiferos en España. Fuente: Martín Pantoja et al. (1994).

\begin{tabular}{lcc}
\hline Catchment & $\begin{array}{c}\text { Number of } \\
\text { wetlands }\end{array}$ & $\begin{array}{c}\text { Overall wetland } \\
\text { area (Ha) }\end{array}$ \\
\hline Northern & 4 & 77 \\
Duero & 16 & 574 \\
Tajo & 2 & 24 \\
Guadiana & 35 & 2.068 \\
Guadalquivir & 6 & 125 \\
Guadalete-Barbate & - & - \\
Southern & 7 & 1.923 \\
Segura & 1 & 10 \\
Júcar & 11 & 2.458 \\
Ebro & 12 & 6.745 \\
Inner Catalonia & 7 & 370 \\
Balearic Islands & - & - \\
Total & 101 & 14.374 \\
\hline
\end{tabular}


Table 3. Spanish limnosystems for which groundwater effects have been reported since the birth of the journal Limnetica. Limnosistemas españoles para los cuales se han referido efectos de las aguas subterráneas desde el comienzo de la publicación de Limnetica.

\begin{tabular}{|c|c|c|}
\hline Site/Lugar & $\begin{array}{l}\text { Major catchment/ } \\
\text { Cuenca Hidrográfica }\end{array}$ & Reference/Referencia \\
\hline Banyoles lake & Inner Catalonia & $\begin{array}{l}\text { Casamitjana \& Roget (1993), Colomer et al. }(2001) \text {, } \\
\text { García-Gil et al. }(1996), \text { Roget \& Casamitjana (1987), } \\
\text { Serra et al. }(2002,2005)\end{array}$ \\
\hline Jarama lakes & Tajo & $\begin{array}{l}\text { Álvarez-Cobelas et al. (1999, 2005c), CEDEX (2001), } \\
\text { Domínguez (2002), Himi (2001), Roblas \& García-Avilés (1999) }\end{array}$ \\
\hline Ruidera lakes & Guadiana & Álvarez-Cobelas et al. (2006) \\
\hline $\begin{array}{l}\text { Doñana sandy ponds } \\
\text { and marshes }\end{array}$ & Guadalquivir & $\begin{array}{l}\text { de Castro \& Muñoz-Reinoso (1997), Muñoz-Reinoso }(1995,1996) \text {, } \\
\text { Sacks et al. (1992), Suso \& Llamas (1993) }\end{array}$ \\
\hline Duero sandy wetlands & Duero & Rey-Benayas (1991), Rey-Benayas et al. (1990) \\
\hline SW Madrid wetlands & Tajo & González-Besteiro (1992) \\
\hline $\begin{array}{l}\text { L'Empordá wetlands } \\
\text { ("aiguamolls") }\end{array}$ & Inner Catalonia & Quintana (2002), Quintana et al. (1998) \\
\hline La Safor wetland & Júcar & Rodrigo et al. $(2001,2003)$ \\
\hline Tablas de Daimiel wetland & Guadiana & Álvarez-Cobelas et al. (2001) \\
\hline Chícamo river & Segura & Vidal-Abarca et al. (2000) \\
\hline $\begin{array}{l}\text { Sea-side intermittent } \\
\text { streams ("ramblas") }\end{array}$ & Segura & Moreno et al. (1995) \\
\hline Albufera de Valencia wells & Júcar & Alonso \& Miracle (1987), Miracle et al. (1995), Soria (1993) \\
\hline Pyrenean springs & Ebro & $\begin{array}{l}\text { Roca (1990), Roca \& Baltanás (1993), Roca \& Gil (1992), } \\
\text { Roca et al. (1992), Sabater \& Roca }(1990,1992)\end{array}$ \\
\hline
\end{tabular}

Campillos lake complex (Málaga; Benavente \& Rodríguez, 1997). Local, intermediate, and regional flows are also responsible for patterns of inundation of sandy ponds in Doñana National Park (Sacks et al., 1992; MuñozReinoso, 1996) and in SW ponds of the Madrid aquifer (González-Besteiro, 1992).

Southeastern intermittent and permanent streams may also have groundwater discharge and recharge (Moreno et al., 1995; Vidal-Abarca et al., 2000), in some places at the scale of tenths of metres (Vidal-Abarca et al., 2000). The Upper Guadiana River and its tributaries in the Lagunas de Ruidera Natural Park receive discharged groundwater, but they have not been computed as yet. It is very likely that many other Spanish streams are fed by groundwater, but the SAIH (acronym for the Spanish Network for River Discharge Measurement) has not been designed to study that process.

\section{OTHER EFFECTS ON LIMNOPHYSICS}

Groundwater entering the Banyoles Lake (Girona) has been shown to resuspend sediments, also enhancing lutocline motions upwards up to $20 \mathrm{~m}$ in periods of average groundwater inflow (Casamitjana \& Roget, 1993). Since that groundwater has a nearly constant temperature $\left(17-19{ }^{\circ} \mathrm{C}\right)$ throughout the year, a hydrothermal plume is often developed, also entraining cold hypolimnion water into the base of the seasonal thermocline of the lake. The plume spreads laterally at the level of neutral buoyancy, thus behaving as a horizontal baroclinic intrusion (Colomer et al., 2001). This plume experiences a strong seasonality because it is controlled by thermocline dynamics; i.e. it is constricted to the hypolimnion during stratifying periods but it spreads throughout the whole water column when Autumn thermal circulation is fully established (Serra et al., 2002). A similar phenomenon has been found in Las Madres lake (Madrid), with groundwater inflow of roughly constant temperature $\left(13-14^{\circ} \mathrm{C}\right)$, promoting a lutocline of a much shorter behaviour (ÂlvarezCobelas, unpublished data), that delays complete mixing of the whole water column for more than a month (Álvarez-Cobelas et al., 2005c). Double diffusion processes, associated with groundwater inflows, have also been reported for both lakes (Serra et al., 2005; Álvarez-Cobelas et al., 2005c). 


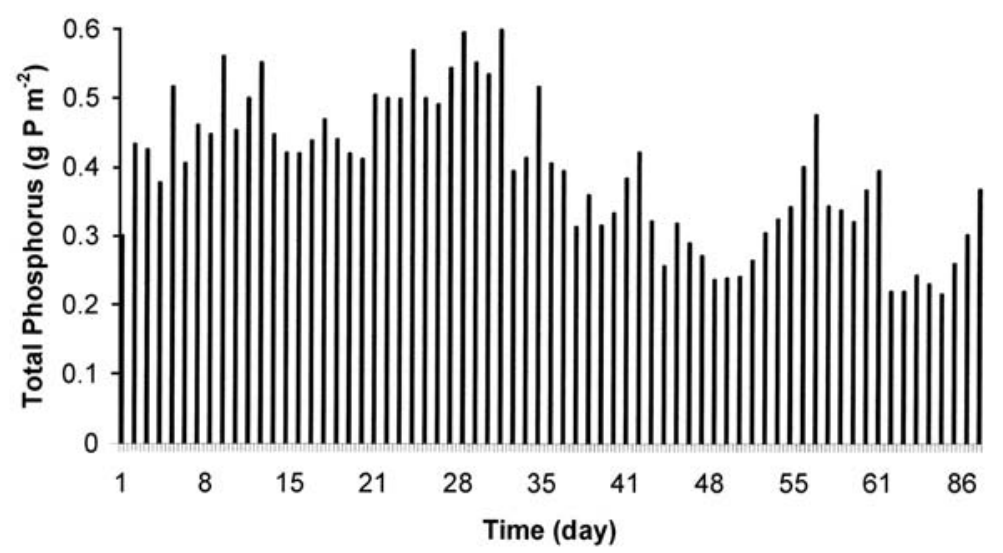

Figure 3. Daily total phosphorus concentration per unit of surface present during 93 consecutive days at the 1991 transition of late stratification-to-early mixing in Las Madres lake (Central Spain). Unpublished data. Concentración diaria del fósforo total por unidad de superficie presente durante 93 días consecutivos de la transición de la estratificación tardía al inicio de la mezcla de 1991 en la laguna de Las Madres (Centro de España). Datos inéditos.

\section{EFFECTS ON LIMNOCHEMISTRY}

Conservative hydrochemistry is one of the main targets of the study of springs. Roca (1990) has undertaken a thorough study on 207 Pyrenean springs in Huesca and Lleida, attempting a typologic synthesis on a wide range of limnological features. Two complex factors are responsible for most of the observed hydrochemical variability: solubilization plus water residence time (42\% explanation of overall variance) and geochemical substrate $(12 \%)$, but there is a group of springs, seemingly heavily dependent on the hypogean environment, where expected hydrochemical patterns do not hold. Also, seaside intermittent streams of Murcia may have groundwater inflows upstream, comprised of magnesium chloride salts (Moreno et al., 1995).

Springs surrounding Albufera de Valencia lake have high ionic strength and nitrate content, but are of oligo-mesotrophic nature, thus reflecting the low concentrations of phosphorus and ammonia in the groundwater they come from (Soria, 1993); this result is striking because in recent decades the lake has become hypertrophic as a result of sustained wastewater inputs over time (Romo et al., 2005), but springs partially feeding it are not. That oligo-mesotrophic status is also common in springs of La Safor wetland (Valencia), which also drain to hypertrophic areas of the marsh (Rodrigo et al., 2001).
Groundwater conductivity and the length of groundwater flow are linearly correlated with each other in the vicinity of sandy wetlands of the Duero basin $\left(\mathrm{r}^{2}=0.65 \mathrm{p}<0.01\right.$; Rey-Benayas et al., 1990), that relationship being of interest for plant community structure in those wetlands (see below).

In seepage lakes located in alluvial plains, groundwater flows may result in depleting inlake areal phosphorus concentration during autumn circulation (Fig. 3). The lake setting in the plain, viz. being close to the river or not, may change seston sedimentation patterns (Fig. 4). In Campillo lake, a hypertrophic seepage lake located very close to Jarama river, phosphorus sedi-

Table 4. Water renewal time (in years) of Ruidera lakes. Data source: Álvarez-Cobelas et al. (in press and unpublished). Tiempo de renovación del agua (en años) de las lagunas de Ruidera. Fuente: Álvarez-Cobelas et al. (en prensa y datos inéditos).

\begin{tabular}{lccc}
\hline Lake & \multicolumn{3}{c}{ Year } \\
\cline { 2 - 4 } & $\mathbf{2 0 0 0}$ & $\mathbf{2 0 0 1}$ & $\mathbf{2 0 0 4}$ \\
\hline Conceja & 9.14 & 4.08 & 0.10 \\
Tomilla & 10.30 & 4.60 & 0.12 \\
Tinaja & 11.19 & 5.00 & 0.11 \\
San Pedra & 12.38 & 3.91 & 0.15 \\
Lengua & 14.47 & 2.00 & 0.14 \\
Santos Morcillo & 32.50 & 3.96 & 0.12 \\
Colgada & 262.12 & 270.31 & 0.11 \\
Rey & 111.21 & 114.69 & 0.13 \\
Cueva Morenilla & 130.10 & 132.56 & 0.14 \\
\hline
\end{tabular}


mentation rates are not much higher $(0.047 \pm$ $\left.0.018 \mathrm{mg} \mathrm{P} \mathrm{m}^{-2} \mathrm{~d}^{-1}\right)$ than those in Las Madres lake $\left(0.034 \pm 0.020 \mathrm{mg} \mathrm{P} \mathrm{m}^{-2} \mathrm{~d}^{-1}\right)$, a mesotrophic seepage lake away from riverine influence. It is well known that river Jarama in the area of Campillo lake acts recharging the aquifer and the lake (Himi, 2001); so riverine-driven groundwater inflow to Campillo lake might reduce phosphorus sedimentation. Total seston sedimentation has been shown to be high close to the hydrother- mal plume of Banyoles lake, reaching values up to $25 \mathrm{~g} \mathrm{~m}^{-2} \mathrm{~d}^{-1}$ (Serra et al., 2005). Such a silt deposition can be observed embedded with biocalcarenites in littoral sediments of that lake.

Groundwater flows appear to be the main cause of the differential confinement of nutrients in L'Empordá wetland (Girona; Quintana et al., 1998), whereby nitrate is easily washed out but phosphorus accumulates, thus increasing eutrophication of this wetland.
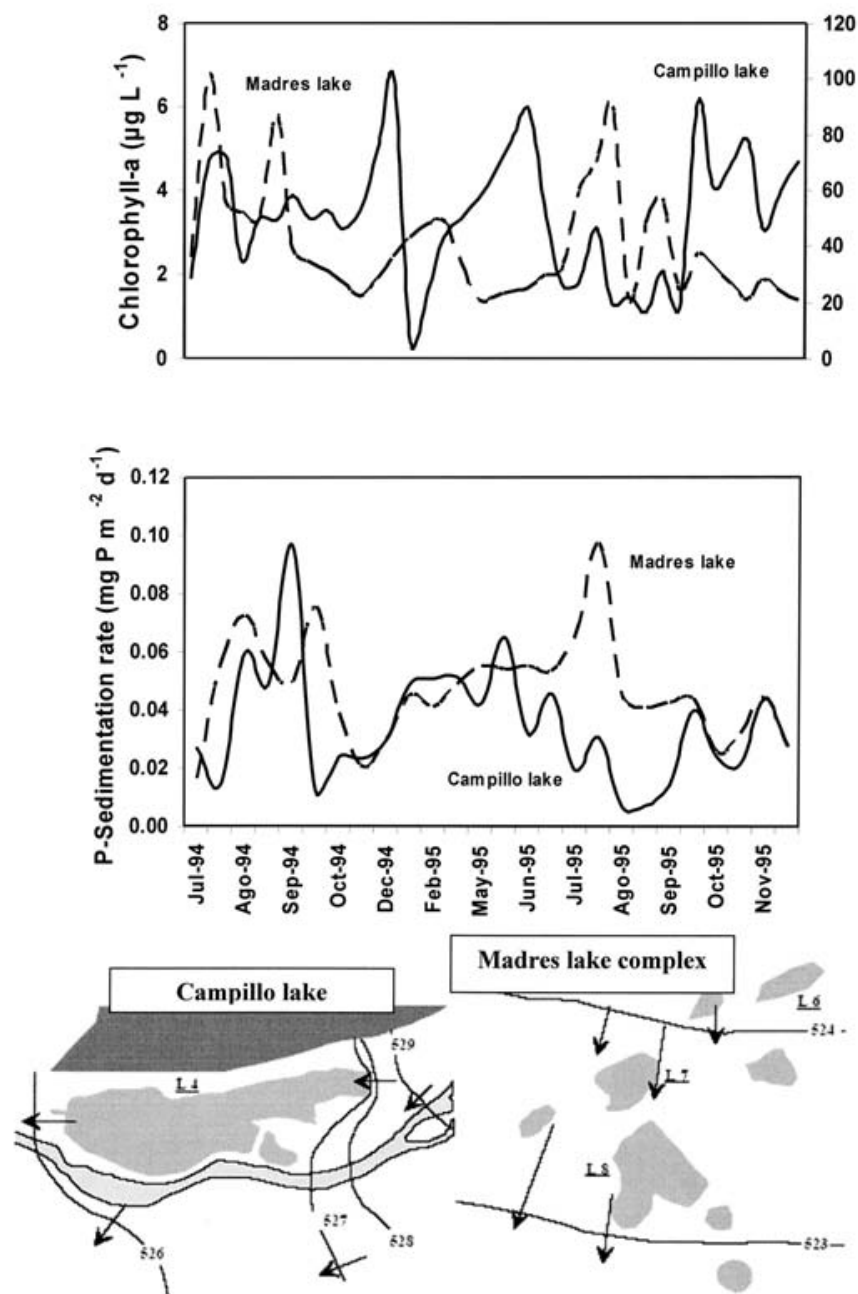

Figure 4. Chlorophyll-a in the mixed column and sedimentation rate of total phosphorus in two Central Spanish lakes. Both lakes lie on an alluvial plain, but Las Madres lake is a mesotrophic seepage lake complex, solely influenced by the alluvial aquifer, whereas Campillo lake is a hypertrophic seepage lake, influenced by groundwater strongly-dependent upon a heavily polluted stream (Jarama river). Scale for chlorophyll for the Campillo lake is the one on the right. Groundwater movement in the vicinity of the lakes is also shown in the lower pictures (Himi, 2001). Unpublished data. Clorofila "a" en la capa de mezcla y tasa de sedimentación del fósforo total en dos lagos del Centro de España, situados en una llanura aluvial. Las Madres es un conjunto de cubetas mesotróficas, influidas únicamente por el acuifero, mientras que El Campillo es un lago hipertrófico, afectado por aguas subterráneas muy dependientes de las entradas de un río muy contaminado (el río Jarama). La escala de la clorofila para el lago de El Campillo es la de la derecha. También se representa, en las figuras inferiores, el flujo del agua subterránea en las proximidades de los lagos (Himi, 2001). Datos inéditos. 


\section{EFFECTS ON THE LIMNOBIOTA}

Obviously, they can be more clearly seen in environments of groundwater upwelling, say, springs. In addition to the plethora of Margalef's biological observations in the forties and fifties in North and Central Spain (for example see his 1946, 1948, 1949, 1950, 1952 and 1955 papers), there have been some studies on the biota of springs that address this topic more recently. In his $\mathrm{Ph} . \mathrm{D}$. thesis, Roca has carried out a thorough study of Pyrenean springs (see Roca, 1990) that has enabled him and his coworkers to outline the main effects of groundwater discharge on spring assemblages of diatoms, turbellarians, mayflies, water mites and ostracods. Ionic content and current velocity appear to be the dominant factors affecting distribution of the 198 diatom species recorded in these springs (table 2 of Sabater \& Roca, 1990), where peculiar environmental factors, such as dim light, high temperature and salinity, could be responsible for the $40 \%$ variability of diatom distribution left unexplained by the two most important factors. Roca et al. (1992) recorded four species of turbellarians in some 50 springs, suggesting that interspecific competition explain the presence of single species in every spring, water temperature and current velocity being the most important abiotic factors shaping the distribution of the observed species. 22 taxa of hydracnellae have been found by Roca \& Gil (table 1 of their 1992 paper), with substrate rocks and water renewal as the main factors explaining their distribution. 21 ostracod species have been reported in the same survey (table 1 of Roca \& Baltanás, 1993), but high mineralization and low flow enhance ostracod species richness in those springs.

Barquín \& Death (2004) have studied the contrasting faunas of some springs and nearby rivers in Cantabria (N Spain), showing a switch between species richness and density: invertebrate density is higher in springs, but species richness is higher in streams. Predation effects by the amphipod Echinogammarus strongly shape communities in springs. Chlorophyll-a, as a surrogate for periphyton biomass, is much higher in springs than in streams and it is the factor showing the highest explanatory power, albeit weak, of the faunal patterns observed.

Phytoplankton biomass, as ascertained by chlorophyll-a, also experiences the contrasting effect of the position of lakes in Madrid alluvial plains. Seepage lakes located close to nutrientrich rivers develop higher phytoplankton biomass $\left(47.9 \pm 24.6 \mu \mathrm{g} \mathrm{Chl-a} \mathrm{L^{-1 }}\right.$ in 1995) than seepage lakes $\left(2.5 \pm 1.2 \mu \mathrm{g}\right.$ Chl-a $\left.\mathrm{L}^{-1}\right)$ farther away from such rivers (Fig. 4), despite the fact that neither is fed by riverine water via surface flow. In the

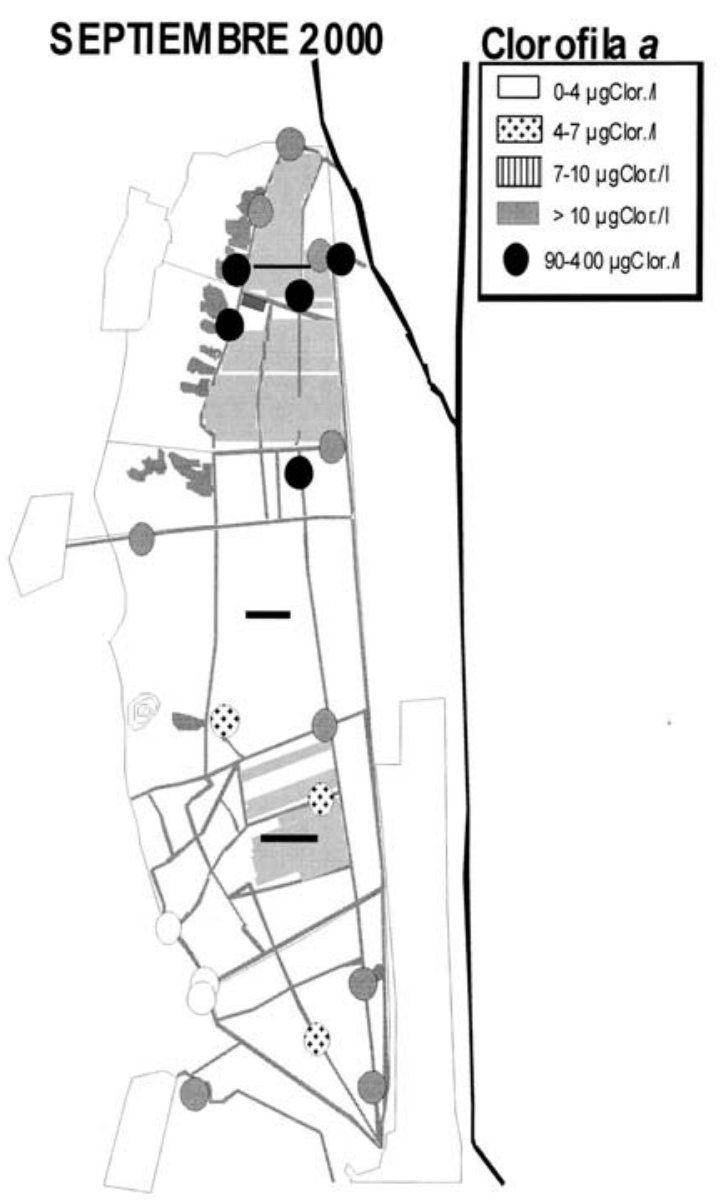

Figure 5. Chlorophyll-a concentration in La Safor wetland in September 2000. White circles represent areas of lower chlorophyll-a, which increases along with the gray scale of the circles. Data from Rodrigo et al. (2001). Concentración de la clorofila "a" en el humedal de La Safor en Septiembre de 2000. Los círculos blancos representan las zonas de menor concentración, la cual se incrementa siguiendo la escala de grises de los círculos. Datos de Rodrigo et al. (2001) 
Table 5. Indicator species organisms on recharge and discharge wetlands, from the Madrid aquifer; discharge wetlands are fed by groundwater. Data source: González-Besteiro (1992). Especies de organismos indicadores en humedales de recarga y descarga del acuifero de Madrid; los humedales de descarga se alimentan con aguas subterráneas. Fuente: González-Besteiro (1992).

\begin{tabular}{cccc}
\hline In recharge wetlands & In discharge wetlands & Regional flow \\
\cline { 2 - 4 } & Local flow & $\begin{array}{c}\text { Regional flow } \\
\text { (alkaline chemistry) }\end{array}$ & (mixed chemistry) \\
\hline Cyzicus grubei & Ranunculus sp. & Chara vulgaris & Ruppia drepanensis \\
Chirocephalus $\mathrm{sp}$. & Daphnia obtusa & Lymnaea peregra & Alona salina \\
Triops cancriformis & Aeschna mixta & Lymaea truncatula & Arctodiaptomus salinus \\
Alona azorica & Ischnura pumilio & Chydorus sphaericus & Arctodiaptomus wierzejskii \\
Moina brachyata & Lestes virens & Simocephalus vetulus & Cletocamptus retrogressus \\
Mixodiaptomus incrassatus & & & \\
\hline
\end{tabular}

"ullals" (freshwater springs) of La Safor wetland, Rodrigo et al. (2001) found lower chlorophyll-a concentrations when light was not limiting (September) than in the remaining wetland (Fig. 5). The ecological stability of those springs is higher than that of other areas of the wetland (Rodrigo et al., 2001). Groundwater upwellings importantly contribute to spatial heterogeneity that drives the species richness recorded in that wetland (128 phytoplankton and 126 zooplankton species; Rodrigo et al., 2003), which is higher than that in other wetlands, such as La Safor, experiencing strong polluting inputs.

"Ullals" surrounding Albufera de Valencia lake can be considered as refuges for rare species of zooplankton. Alonso \& Miracle (1987) recorded some interesting rotifers and crustaceans in those springs, such as the copepods Eucylops graetieri, Microcylops rubellus major and Horsiella brevicornis, the cladoceran Dunhevedia crassa, and the rotifers Asplachnopus multiceps, A. hyalinus, and Euchlanis dapidula. The species richness of rotifers in Albufera springs is very remarkable, because another study (Miracle et al., 1995) recorded 107 species (see their table 1), including many taxa only known to occur in very restricted geographical areas (Lecane pides, Erignata saggitoides, Dicranophorus hercules, Paradicranophorus hudsoni).

Crustacean, dragonfly, molluscan, and plant species indicating distinct flows of groundwater have also been recorded in Central Spain by
González-Besteiro (1992), whose recorded biological species enabled her to distinguish between recharge and discharge wetlands, the latter being fed by local or regional (either alkaline or mixed) groundwater flows (Table 5).

González-Besteiro's results are but one outcome of a research line relating biological species and groundwater, which has been explored by the González-Bernáldez school, also providing evidences of that relationship in sandy wetlands of Central and Southwestern Spain. Long-range groundwater flow (i.e. regional) results in the development of halophytic species, such as Juncus subulatus, Limonium costae, and Suaeda vera, that thrive in sulphate and chloride-rich Duero wetlands; local flows promote community compositions rich in glycophytic (Mentha suaveolens, Juncus inflexus, Poa trivialis) and alkalinophytic plants (Festuca arundinacea, Juncus acutus, J. gerardi) (Rey-Benayas et al., 1990). Furthermore, the depth of the hydraulic head and groundwater chemistry interact to produce four different plant communities in discharge wetlands of the Doñana National Park: $1^{\text {st }}$ higher mineralized discharges (conductivity > $1500 \mu \mathrm{S} \mathrm{cm}^{-1}$ ) are related with Tamarix canariensis and Juncus acutus; $2^{\text {nd }}$ ) mid-mineralized discharges (conductivity $\approx 500 \mu \mathrm{S} \mathrm{cm}^{-1}$ ) promote Scirpus holoschoenus and Juncus maritimus growth; $3^{\text {rd }}$ ) mid-mineralized, chloride-rich discharges are indicated by Juncus acutiflorus and $J$. effusus; and $4^{\text {th }}$ ) lower mineralized inflows 

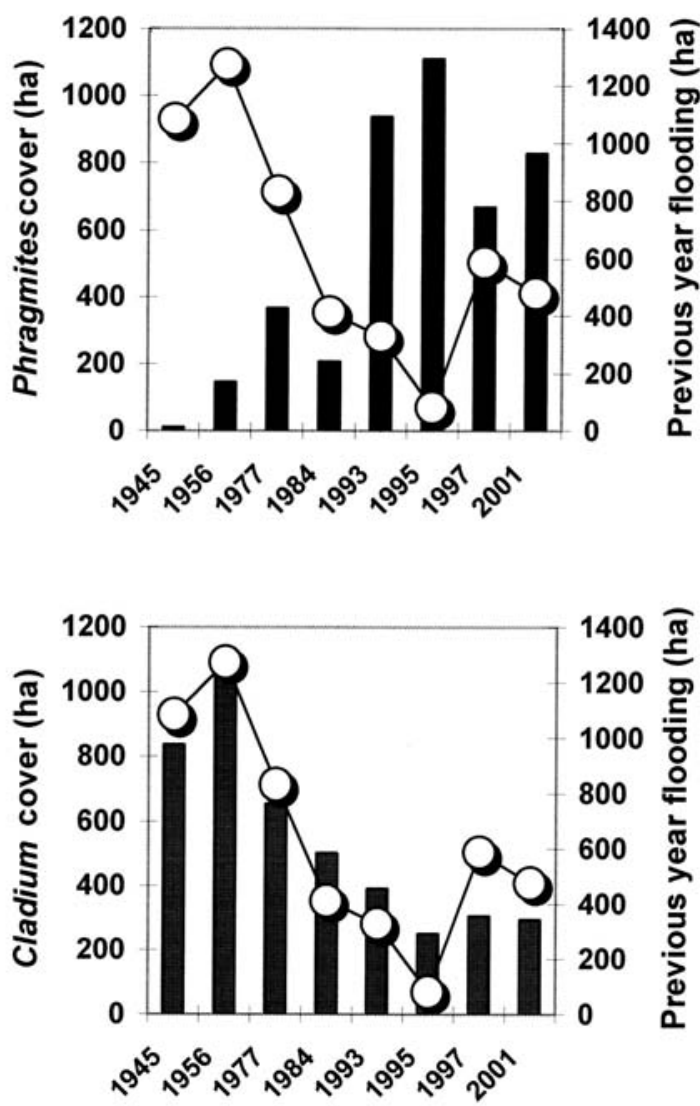

Figure 6. Annual cover (vertical bars, left-hand scale) of the two main species of emergent macrophytes in Las Tablas de Daimiel National Park and average flooding area in the previous year (circles, right-hand scale) during the period 1945-2002. Groundwater supply ended in 1986 because of aquifer overexploitation. Data published in Álvarez-Cobelas et al. (2005b). Cobertura anual (barras verticales, escala de la izquierda) de las dos principales especies de macrófitos emergentes en el Parque Nacional Tablas de Daimiel y superficie inundada promedio en el año anterior (círculos, escala de la derecha) durante el periodo 1945-2002. Dejó de haber aportes de aguas subterráneas en 1986 debido a la sobreexplotación del acuífero. Datos publicados en Álvarez-Cobelas et al. (2005b).

(conductivity $<300 \mu \mathrm{S} \mathrm{cm} \mathrm{cm}^{-1}$ ) result in two distinct plant communities mediated by the depth of the water table (Muñoz-Reinoso, 1995).

The outstanding, albeit delayed, effects of groundwater discharge into surface wetlands could be supported by the counterexample of Las Tablas de Daimiel wetland. When the underlying aquifer contributed waters for wetland flooding, the dominant emergent vegetation was comprised by the cut-sedge Cladium mariscus, whereas this plant dominance was substitut- ed by the reed Phragmites australis once that groundwater effect was over (Fig. 6; ÁlvarezCobelas et al., 2005b). Groundwater flooding provided longer hydroperiod and less fluctuating hydrolevels for many areas of the wetland that partly benefited Cladium. Later, the cover extent of that plant greatly diminished, being substituted by Phragmites, much better adapted to the higher water fluctuations that arose when groundwater supply was discontinued as a result of aquifer overexploitation by growing irrigation (Álvarez-Cobelas et al., 2001).

Bacteria and fish are also suspected to suffer from indirect effects of groundwater inflows. García-Gil et al. (1996) suggest that the differential development of suspended layers pushed upward in different basins of Banyoles Lake by groundwater inflows, change underwater light climate, thus affecting seasonal dynamics of autotrophic sulphur bacteria in each basin. Serra et al. (2002) report that the hydrothermal plume may reduce the vertical habitat suitable for fish, that are restricted to areas above the plume, because suspended silt impairs the light climate that those fish (Perca and Rutilus) need to feed on their preys.

\section{FUTURE PROSPECTS}

The preceding pages have attempted to outline many studies dealing with the effects of groundwater on Spanish limnosystems. Despite its fragmentation, those studies demonstrate that groundwater happens to act upon many different features of aquatic environments, but results are very preliminary as yet. That groundwater and the solutes they transport impinge on surface waters is an obvious outcome of the water cycle. What is not as obvious is the strong tie that groundwater may develop with surface waters in Mediterranean environments (Álvarez-Cobelas et al., 2005a), where rainfall seasonality and frequent unevenness pose very strict limits to surface water availability, but whose limits can be partly circumvented on account of groundwater inflows into limnosystems. This could be another facet of the supply-side ecology that Margalef 
(1980: 191) advocated when he talked about "external energy". Turbulent flow is of course external or "exosomatic", as he has later coined, but solutes and materials transported by groundwater can also enhance (or depress) biological productivity in freshwaters (i.e. they are energycontrollers), groundwater itself supplying a suitable environment when surface water is depleted.

Anyway, all these contentions are preliminary enough to satisfy our scientific thirst. In its present state most Spanish limnologists work on a very local basis (a given lake, reservoir, stream or wetland), whereas most Spanish hydrogeologists work at a regional scale (a more or less large aquifer), and both scales hardly match. However, most Mediterranean limnosystems are very small, their basins having a paramount influence on their ecology (ÁAlvarez-Cobelas et al., 2005a). Spanish limnological studies on basin effects, that obviously include groundwater effects as I have already shown, are very scarce. Also, groundwater effects happen to be dictated by the hydraulic head field in the surroundings of the studied limnosystem, often implying the interplay of regional and local groundwater flows (Winter, 1999). It is then time both, for Spanish limnologists to gain a landscape approach and for Spanish hydrogeologists to gain a local focus. Another drawback for improving such a relationship is the expensiveness of some hydrogeological techniques. In order to study the groundwater field surrounding a given lake or wetland, it is necessary to have nested piezometers around it, but these devices exist very infrequently and are expensive to build. In sandy basins they can be profitably substituted by hand-operated piezometers that are reasonably cheaper (Winter et al., 1988), but in calcareous basins environmental managers (because many valuable limnosystems occur in environmentally-protected areas) must deal with the expenses needed to build piezometers in numbers enough to cover the whole local area to be surveyed.

The superposition of regional and local flow systems associated with surface water bodies results in complex interactions between groundwater and surface water and climate in all land- scapes, often including effects of limnosystem topographic setting. Such a complexity promotes very different patterns of water and solute transport into and out of the limnosystems, impinging on water renewal and exchange of materials. Those processes have been documented in glacial, dune, coastal, karst, and alluvial environments of U.S.A. (Winter, 1999), but none in Spain, despite some obvious similarities of local climate and geological substrate. Among the many features resulting from the connection of limnetic and groundwater environments in Spain that have not been explored as yet, are the responses of limnosystems to transient conditions of local and regional groundwater flow. Such as the effects of transpiration of emergent vegetation on the transport of groundwater solutes into playa lakes; the effects of changing aquifer geometry (3-D values of transmissivity and permeability) on limnosystem functioning; the effects of short, middle and long-term (including those of climate change) variability of rainfall in aquifer recharge from and discharge into limnosystems; the effects of man-made impacts on aquifer quantity and quality of water that may affect limnosystems later; and many more. Some of them are specifically known from other places (Winter, 1999; Winter \& Rosenberry, 1995; Webster et al., 1996; 1ter.limnology.wisc.edu); others have even been modeled (Nield et al., 1994; Smith \& Townley, 2002), but most of this knowledge has been achieved in cold temperate areas of the world, quite different from Spanish ones. It is clear that the advancement of groundwater-mediated limnology in Spain should rely on the match between landscape-oriented limnology and site-oriented hydrogeology that must result in updating and expanding Naumann (1932) and Margalef (1951) ideas of regional limnology. There is a world ahead to be gained.

\section{ACKNOWLEDGEMENTS}

The life and work of Ramón Margalef has always been an inspiration to me. His very talented scientific endeavors and pursuits in very 
hard times for the ever-lasting illiterate Spain have always been very encouraging and, not having been one of his students, I owe my dedication to limnology to one of his papers published in Jano: Medicina y Humanidades (a Spanish Medicine Journal) sometime in the seventies. This overview is an outcome of my interaction with some Spanish botanists, limnologists and hydrogeologists over time, such as Santos Cirujano (Real Jardín Botánico de Madrid, CSIC), Carmen Rojo and María Antonia Rodrigo (Instituto Cavanilles de Biodiversidad, Univ. Valencia), Youssef Himi (Spanish Ministry of Home Affairs) and Esperanza Montero (Dept. Geodinámica, Univ. Complutense de Madrid), and it is a pleasure to acknowledge them the countless hours of talking about anything, even groundwater-mediated limnology. Juan Soria (Confederación Hidrográfica del Júcar), Javier Vidal (Univ. Girona), Carmen Rojo, María Antonia Rodrigo and José Barquín (Univ. Cantabria) have sent me papers and information. Carmen Rojo read carefully a preliminary draft of the manuscript. And last but not least, María Antonia Rodrigo translated the abstract into Catalan, as an homage to Ramón Margalef native language.

\section{REFERENCES}

ALONSO, M. T. \& M. R. MIRACLE. 1987. Estudio comparativo del zooplancton en tres ullales del Parque Natural de la Albufera de Valencia. Limnetica, 3: 263-272.

ÁlVAREZ-COBELAS, M. \& S. CIRUJANO (eds.) 1996. Las Tablas de Daimiel: Ecología acuática y Sociedad. Ministerio de Medio Ambiente. Organismo Autónomo Parques Nacionales, Madrid. 384 pp.

ÁLVAREZ-COBELAS, M., P. RIOLOBOS, Y. HIMI, S. SÁNCHEZ CARRILLO, J. GARCÍA AVILÉS \& J. HIDALGO. 2000. Estudio físico-químico de los Ambientes estancados del Parque Regional del Sureste de la Comunidad de Madrid. Consejería de Medio Ambiente, Serie Documentos no 29. Comunidad Autónoma de Madrid. Madrid. 65 pp +1 disquete.

ÁlVAREZ-COBELAS, M., S. CIRUJANO \& S. SÁNCHEZ CARRILLO. 2001. Hydrological and botanical man-made changes in the Spanish wetland of Las Tablas de Daimiel. Biol. Conservation, 97: 89-97.

ÁlVAREZ-COBELAS, M., C. ROJO \& D. G. ANGELER. 2005a. Mediterranean limnology: current status, gaps and the future. J. Limnol., 64: 13-29.

ÁlVAREZ-COBELAS, M., J. CATALAN \& D. GARCÍA DE JALÓN. 2005b. Impactos sobre los ecosistemas acuáticos continentales. In: Evaluación preliminar de los Impactos del Cambio Climático en España. J. M. Moreno (ed.): 113-146. Ministerio de Medio Ambiente y Universidad de Castilla-La Mancha. Madrid.

ÁlVAREZ-COBELAS, M., J. L. VELASCO, M, VALLADOLID, A. BALTANÁS \& C. ROJO. 2005 c. Daily patterns of mixing and nutrient concentrations during early autumn circulation in a small sheltered lake. Freshwat. Biol., 50: 813-829.

ÁlVAREZ-COBELAS, M., S. CIRUJANO, E. MONTERO, C. ROJO, M. A. RODRIGO, E. PIÑA, J. C. RODRÍGUEZ-MURILLO, O. SORIANO, M. ABOAL, J. P. MARÍN \& R. ARAUJO (in press). Ecología acuática y Sociedad de las Lagunas de Ruidera. CSIC. Madrid.

ÁlVAREZ-COBELAS, M., S. CIRUJANO, C. ROJO, M. A. RODRIGO, E. PIÑA, J. C. RODRÍGUEZ-MURILLO \& E. MONTERO. (submitted). Effects of changing rainfall on the limnology of a mediterranean, flowthrough-seepage chain of lakes. Internat. Rev. Hydrobiol.

BARQUÍN, J. \& R. G. DEATH. 2004. Patterns of invertebrate diversity in streams and freshwater springs in Northern Spain. Arch. Hydrobiol., 161: 329-349.

BENAVENTE, J. \& M. RODRÍGUEZ. 1997. Análisis cuantitativo de los flujos subterráneos en las lagunas de Campillos (Málaga). Limnetica, 13(1): 15-23.

CASAMITJANA, X. \& E. ROGET. 1993. Resuspension of sediment by focused groundwater in Lake Banyoles. Limnol. Oceanogr., 38: 643-656.

CEDEX, 1997. Estudio de la Hidrología isotópica en la Cuenca del Alto Guadiana. I. Unidad Hidrogeológica 04-06, Lagunas de Ruidera, Campo de Montiel. Informe 51-493-1-012. Ministerio de Fomento. Madrid. 155 pp.

CEDEX, 2001. Cartografía temática de Ecosistemas acuáticos leniticos del Parque Regional del Sureste (Madrid) por Teledetección aerotransportada. Informe 44-501-5-012. Ministerio de Fomento. Madrid. 103 pp. + anexos. 
COLOMER, J., T. SERRA, J. PIERA, E. ROGET \& X. CASAMITJANA. 2001. Observations of a hydrothermal plume in a karstic lake. Limnol. Oceanogr., 46: 197-203.

DE CASTRO, F. \& J. C. MUÑOZ-REINOSO. 1997. Model of long-term water-table dynamics at Doñana National Park. Water Res., 31: 2586-2596.

DOMÍNGUEZ GÓMEZ, J. A. 2002. Estudio de la Calidad del Agua de las Lagunas de Gravera por Teledetección. Tesis Doctoral. Universidad de Alcalá de Henares. 461 pp.

FOIX, J. V. 1936. Sol, i de Dol. Edició de 1985 a cura de Jaume Vallcorba. Cuaderns Crema. Barcelona. $86 \mathrm{pp}$.

GARCIAA-GIL, L. J., X. CASAMITJANA \& C. A. ABELLA. 1996. Comparative study of two meromictic basins of Lake Banyoles (Spain) with sulphur phototrophic bacteria. Hydrobiologia, 319: 203-211.

GOLTERMAN, H. L. 1975. Physiological Limnology. Elsevier Scientific Publishing Company, Amsterdam. 489 pp.

GONZÁLEZ-BERNÁLDEZ, F. 1992a. Ecological aspects of wetland/groundwater relationships in Spain. Limnetica, 8: 11-26.

GONZÁLEZ-BERNÁLDEZ, F. 1992b. Los Paisajes del Agua: Terminología popular de Humedales. J.M. Reyero, editor. Madrid. 257 pp.

GONZÁLEZ-BESTEIRO, A. 1992. Limnología de las Formaciones palustres situadas sobre el Acuifero de Madrid. Análisis de las Relaciones entre Aguas superficiales y subterráneas. Tesis Doctoral. Universidad Autónoma. Madrid. 334 pp. + apéndices.

HERNÁNDEZ-PACHECO, E. 1932. El enigma del Alto Guadiana. Rev. Serv. Soc. Agrar. Estad. Agric. Soc., 8: 851-859.

HIMI, Y. 2001. Hidrología y Contaminación en el Parque Regional del Sureste de la Comunidad Autónoma de Madrid. Tesis Doctoral. Facultad de Geología. Universidad Complutense. Madrid. 304 pp. +1 CD.

HYNES, H. B. N. 1975. The stream and its valley. Verh. Internat. Verein. Limnol., 19: 1-15.

JOHNSON, L. B. \& S. H. GAGE. 1997. Landscape approaches to the analysis of aquatic ecosystems. Freshwat. Biol., 37: 113-132.

MARGALEF, R. 1946. Materiales para el estudio de la biología del lago de Bañolas (Gerona). Publ. Inst. Biol. Apl. Barcelona, 1: 27-78.

MARGALEF, R. 1948. Flora, Fauna y Comunidades bióticas de las Aguas dulces del Pirineo de la
Cerdaña. Instituto de Estudios Pirenaicos (CSIC). Jaca. 226 pp.

MARGALEF, R. 1949. Datos para la hidrobiología de la Sierra de Guadarrama. Publ. Inst. Biol. Apl. Barcelona, 6: 5-21.

MARGALEF, R. 1950. Datos para la hidrobiología de la cordillera cantábrica, especialmente del macizo de los Picos de Europa. Publ. Inst. Biol. Apl. Barcelona, 7: 37-76.

MARGALEF, R. 1951. Regiones limnológicas de Cataluña y ensayo de sistematización de las asociaciones de algas. Collect. Bot., 3: 43-67.

MARGALEF, R. 1952. La vida en las aguas dulces en los alrededores del Santuario de Nuestra Señora de Aránzazu (Guipúzcoa). Munibe, 4: 73-108.

MARGALEF, R. 1955. Comunidades bióticas de las aguas dulces del noroeste de España. Publ. Inst. Biol. Apl. Barcelona, 21: 5-85.

MARGALEF, R. 1980. La Biosfera: entre la Termodinámica y el Juego. Editorial Omega. Barcelona. $236 \mathrm{pp}$.

MARTÍN PANTOJA, M., J. M. SANTAFÉ, A. SÁNCHEZ GONZÁLEZ, M. VARELA, C. LÓPEZ ASIO, A. NAVARRO, J. A. LÓPEZ GETA, L. FERNÁNDEZ RUIZ \& P. NAVARRETE. 1994. Libro Blanco de las Aguas Subterráneas. Ministerio de Industria y Energía y Ministerio de Obras Públicas, Transportes y Medio Ambiente. Madrid. $135 \mathrm{pp}$.

MIRACLE, M. R., M. T. ALFONSO, E. VICENTE \& W. KOSTE. 1995. Rotifers of spring pools in the coastal marshland of Albufera of Valencia Natural Park. Limnetica, 11: 39-47.

MORENO, J. L., M. L. SUÁREZ \& M. R. VIDALABARCA. 1995. Hidroquímica de las ramblas litorales de la región de Murcia: variaciones espacio-temporales. Limnetica, 11(1): 1-13.

MUÑOZ-REINOSO, J. C. 1995. Influencia del agua freática sobre la vegetación de las áreas de descarga sobre arenas en la Reserva Biológica de Doñana. Limnetica, 11(2): 9-16.

MUÑOZ-REINOSO, J. C. 1996. Tipología de las descargas sobre arenas de la Reserva Biológica de Doñana. Limnetica, 12: 53-63.

NAUMANN, E. 1932. Grundzüge der regionalen Limnologie. E. Schweizerbart'sche Verlagsbuchhandlung. Stuttgart. $176 \mathrm{pp}$.

NIELD, S. P., L. R. TOWNLEY \& A. B. BARR. 1994. A framework for quantitative analysis of surface water-groundwater interaction: flow geometry in a vertical section. Water Resour. Res., 30: 2461-2475. 
PLINY THE ELDER [Caius Plinii Secundi] (1998 edition). Historia Natural. Libros III-VI. A. FONTÁN et al. (eds.). Editorial Gredos. Madrid. $542 \mathrm{pp}$.

QUINTANA, X. D. 2002. Estimation of water circulation in a Mediterranean salt marsh and its relationship with flooding causes. Limnetica, 21: 25-35.

QUINTANA, X. D., R. MORENO-AMICH \& F. A. COMÍN. 1998. Nutrient and plankton dynamics in a Mediterranean salt marsh dominated by incidents of flooding. Part 1. Differential confinement of nutrients. J. Plankton Res., 20: 2089-2107.

REY-BENAYAS, J. M. 1991. Aguas subterráneas y Ecología. Ecosistemas de Descarga de Acuíferos en los Arenales. ICONA-CSIC. Madrid. $141 \mathrm{pp}$.

REY-BENAYAS, J. M., F. G. BERNÁLDEZ, C. LEVASSOR \& B. PECO. 1990. Vegetation of groundwater discharge sites in the Douro basin, central Spain. J. Vegetation Sci., 1: 461-466.

ROBLAS, N. \& J. GARCÍA-AVILÉS. 1999. Tipificación de las láminas de agua generadas por actividades extractivas del "Parque Regional en torno a los ejes de los cursos bajos de los ríos Manzanares y Jarama" (Madrid, España). Limnetica, 17: 27-36.

ROCA, J. R. 1990. Tipología físico-química de las fuentes de los Pirineos Centrales: síntesis regional. Limnetica, 6: 57-78.

ROCA, J. R. \& M. J. GIL. 1992. Ecological and historical factors affecting distribution of watermites in Pyrenean springs. Arch. Hydrobiol., 125: 227-244.

ROCA, J. R \& A. BALTANÁS. 1993. Ecology and distribution of ostracoda in Pyrenean springs. $J$. Crustacean Biol., 13: 165-174.

ROCA, J. R., M. RIBAS \& J. BAGUÑÁ. 1992. Distribution, ecology, mode of reproduction and karyology of freshwater planarians (Platyhelminthes; Turbellaria; Tricladida) in the springs of the Central Pyrenees. Ecography, 15: 373-384.

RODRIGO, M. A., C. ROJO, X. ARMENGOL \& M. MAÑÁ. 2001. Heterogeneidad espacio-temporal de la calidad del agua en un humedal costero: El Marjal de la Safor (Valencia). Limnetica, 20: 329339.

RODRIGO, M. A., C. ROJO \& X. ARMENGOL. 2003. Plankton biodiversity in a landscape of shallow water bodies (Mediterranean coast, Spain). Hydrobiologia, 506-509: 317-326.

ROGET, E. \& X. CASAMITJANA. 1987. Balance hídrico del lago Banyoles. Actas IV Congr. Esp. Limnol.: 39-46.
ROMO, S., M. J. VILLENA, M. SAHUQUILLO, J. M. SORIA, M. GIMÉNEZ, T. ALFONSO, E. VICENTE \& M. R. MIRACLE. 2005. Response of a shallow Mediterranean lake to nutrient diversion: does it follow similar patterns as in northern shallow lakes? Freshwat. Biol., 50: 1706-1717.

SACKS, L. A., J. S. HERMAN, L. F. KONIKOW \& A. L. VELA. 1992. Seasonal dynamics of groundwater-lake interactions at Doñana National Park, Spain. J. Hydrol., 136: 123-154.

SABATER, S. \& J. R. ROCA. 1990. Some factors affecting distribution of diatom assemblages in Pyrenean springs. Freshwat. Biol., 24: 493-507.

SABATER, S. \& J. R. ROCA. 1992. Ecological and biogeographical aspects of diatom distribution in Pyrenean springs. Brit. Phycol. J., 27: 203-213.

SERRA, T., J. COLOMER, L. ZAMORA, R. MORENO-AMICH \& X. CASAMITJANA. 2002. Seasonal development of a turbid hydrothermal lake plume and the effects on the fish distribution. Water Res., 36: 2753-2760.

SERRA, T., M. SOLER, X. CASAMITJANA, R. JULIÁ \& J. COLOMER. 2005. Behaviour and dynamics of hydrothermal plume in Lake Banyoles, Catalonia, NE Spain. Sedimentology, 52: 795-808.

SMITH, A. J. \& L. R. TOWNLEY, 2002. Influence of regional setting on the interaction between shallow lakes and aquifers. Water Resour. Res., 38: 1171-1184.

SORIA, J. M. 1993. Caracterización físico-química de las surgencias del Parque Natural de la Albufera (Valencia). Actas VI Congreso Español de Limnología: 91-97.

STANKOVIC, S. 1958. Limnologie des lacs karstiques. Verh. Internat. Verein. Limnol., 13: 422-435.

SUSO, J. \& M. R. LLAMAS. 1993. Influence of groundwater development on the Doñana National Park ecosystems (Spain). J. Hydrol., 141: 239269.

TORRENS, J., A. BATLLE, S. NIÑEROLA, F. GONZÁLEZ. \& J. CALVÍN. 1976. Contribución al conocimiento de las relaciones entre los acuíferos del Campo de Montiel y la Llanura Manchega. La leyenda del Guadiana. Hidrogeol. Rec. Hidrául., 1: 398-420.

TÓTH, J. 1963. A theoretical analysis of groundwater flow in small drainage basins. J. Geophys. Res., 68: 4795-4812.

VIDAL-ABARCA, M. R., M. L. SUÁREZ, J. L. MORENO, R. GÓMEZ \& I. SÁNCHEZ. 2000. Hidroquímica de un río de características semiári- 
das (río Chícamo; Murcia). Análisis espacio-temporal. Limnetica, 18: 57-73.

VIDAL-PARDAL, M. 1960. La alimentación subterránea del lago de Bañolas y algunos datos sobre los depósitos lacustres de sus inmediaciones. Min. Obr. Publ. Bol., 7: 23-40.

WEBSTER, K. E., T. K. KRATZ, C. J. BOWSER, J. J. MAGNUSON \& W. J. ROSE. 1996. The influence of landscape position on lake chemical responses to drought in northern Wisconsin, USA. Limnol. Oceanogr., 41: 977-984.

WINTER, T. C. 1981. Uncertainties in estimating the water balance of lakes. Water Res. Bull., 17: 82115.

WINTER, T. C. 1988. A conceptual framework for assessing cumulative impacts on the hydrology of nontidal wetlands. Environm. Managm., 12: $605-$ 620.

WINTER, T. C. 1995. Hydrological processes and the water budget of lakes. In: Physics and
Chemistry of Lakes (A. Lerman, D. M. Imboden \& J.R. Gat, Eds.), 37-62. Springer Verlag. Berlin.

WINTER, T. C. 1999. Relations of streams, lakes, and wetlands to groundwater flow systems. Hydrogeology J., 7: 28-45.

WINTER, T. C. 2003. The hydrology of lakes. In: The Lakes Handbook, Volume 1 (P. E. O'Sullivan \& C. S. Reynolds, Eds.), 61-78. Blackwell Publishing. Oxford.

WINTER, T. C., J. W. LABAUGH \& D. O. ROSENBERRY. 1988. The design and use of a hydraulic potentiomonometer for direct measurement of differences in hydraulic head between groundwater and surface water. Limnol. Oceanogr., 33: 12091214.

WINTER, T. C. \& D. O. ROSENBERRY. 1995. The interaction of ground water with prairie pothole wetlands in the Cottonwood Lake area, east-central North Dakota, 1979-1990. Wetlands, 15: 193211. 